\title{
Influence of genotype and crop year on carotenoids content of peels from Bulgarian tomato cultivars
}

\author{
Milena Nikolova, Donka Taneva, \\ Tsvetko Prokopov, Mima Hadjikinova
}

\author{
University of Food Technologies, Plovdiv, Bulgaria
}

Keywords:

Tomato

Peels

Carotenoids

Genotype

Crop year

\section{Article history:}

Received

27.06.2017

Received in revised form 02.09.2017

Accepted 05.09.2017

\section{Corresponding} author:

Tsvetko Prokopov

E-mail:

tsvetko_prokopov@ abv.bg

DOI:

$10.24263 / 2304-$

974X-2017-6-3-7

\section{Abstract}

Introduction. The aim of this study is to determine the effect of genotype and crop year on the quantity of waste peels from six Bulgarian tomato cultivars generated during their peeling and the carotenoids content of the obtained peels.

Materials and methods. Six Bulgarian tomato cultivars, were grown under open-field conditions at the Maritsa Vegetable Crop Research Institute, Plovdiv, Bulgaria. The combined effect of the investigated factors on the quantity of the waste generated during tomato peeling was established by the two-factor dispersion analysis and by the HPLC analysis the carotenoids contained in tomato peels were determined.

Results and discussion. It was found that tomato genotype has a major effect on the percentage of generated peels during tomato peeling and on its carotenoids content. The average persentage of peels from tomatoes harvested in 2013 year ranged from $2.45 \pm 0.13 \%$ to $5.33 \pm 0.09 \%$. The highest persentage of peels was found for "Carobeta" cultivar and at least for "Topaz". For tomato cultivars cultivated in 2014 crop year the average persentage of the obtained peels varied from $2.98 \pm 0.13 \%$ to $3.50 \pm 0.25 \%$ and the highest quantity of peels was generated from the "Aquarius F1" cultivar and at least from "Carobeta" cultivar of tomato. The obtained peels contained mainly lycopene, betacarotene and lutein. In the first crop year the highest contents of lycopene $(97.16 \pm 0.81 \mathrm{mg} / 100 \mathrm{~g})$ and lutein $(21.22 \pm 0.10 \mathrm{mg} / 100 \mathrm{~g})$ were found in the peels of the "Stella" cultivar of tomato and those of "Carobeta" cultivar had the highest content of betacarotene $(108.48 \pm 1.36 \mathrm{mg} / 100 \mathrm{~g})$, whereas in the second year of survey most of the lycopene $(241.14 \pm 1.24 \mathrm{mg} / 100 \mathrm{~g})$ was contained in the "Aquarius F1" peels, and the beta-carotene $(293.36 \pm 2.00 \mathrm{mg} / 100 \mathrm{~g})$ and lutein $(13.58 \pm 0.15 \mathrm{mg} / 100 \mathrm{~g})$ in the "Stella" tomato peels. Tomato peels of cultivars ,Stella“, „Topaz", „Aquarius $\mathrm{F}_{1}$ “ and „Jacqueline“" are reached in lycopene and betacarotene, whereas the peels of cultivars "Marigold" and „Carobeta“ are suitable source of beta-carotene only. The results indicated the greatest influence of the tomato genotype on lutein content $(69.43 \%)$, followed by beta-carotene $(57.52 \%)$ and peels persentage $(46.55 \%)$. The environmental conditions were found to had a strong influence on the content of peels $(41.66 \%)$ and lycopene $(38.73 \%)$, while the effect on beta-carotene was lower $(14.92 \%)$ and on luteine was very low $(1.63 \%)$.

Conclusions. The amount of lycopene in tomato peels is dependent on genotype and crop year, whereas the beta-carotene and lutein contents were affected mainly by the tomato genotype. 


\section{Introduction}

Tomatoes have an important economic significance in the countries with advanced vegetable production. The good tomato taste and suitability for technological processing in various types of products determine the great importance of this vegetable. The wide distribution and use of tomatoes are mainly due to the established cultivars with different vegetation period, high and stable productivity, resistance to economically important diseases and excellent technological quality.

Production of fresh tomatoes in the word for 2012 amounted to 161.8 million tones and in the EU-27 to 15.2 million tones. The production of tomatoes in Bulgaria for the same year amounted to 94016 tones. According to FAO data, $65-85 \%$ of the fresh tomatoes produced are processed into canned foods [5]. This industrial processing of tomatoes released around $10-40 \%$ of waste products [1].

The tomato peeling operation applied in processing industry generates tomato skin and outer pericarp tissue, named peels, usually creating big environmental problems. However, the by-products of tomato processing contain important biological active substances (vitamin C, polyphenols, lycopene, beta-carotene and etc.), which made this waste material suitable for using in the food industry $[10,15]$.

The quantity of tomato wastes combined with the beneficial characteristics of components of these wastes justifies the great interest of researchers and manufacturers in extracting of carotenoids from this low cost material [16].

The amount of carotenoids in industrial tomato cultivars depends from different factors such as genotype, agricultural practices, soil, climate factors, harvesting date, degree of maturity and post-handling. The reported amount of lycopene in tomato peels ranging from 5 to $100 \mathrm{mg} / 100 \mathrm{~g}[8,9,12,13,14]$.

The valorisation of generated huge quantities of value-added waste tomato material is among the most important global challenges. However, it is necessary to study the quantity and composition of each tomato processing waste to know its potential use for food purposes.

Bulgarian tomato cultivars „Stella“, „Topaz“, „Aquarius F ““, „Jacqueline“, „Marigold“ and „Carobeta" are of the great interest for the canning industry. There are not data in the literature for the effect of tomato genotype and crop year on the quantity of the waste during the tomato peeling and the content of carotenoids in the peels generated from these Bulgarian tomato cultivars. Therefore, to establish this effect was the main aim of present study.

\section{Materials and methods}

\section{Materials}

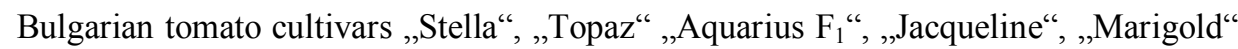
and „Carobeta“, were grown under open-field conditions at the Maritsa Vegetable Crop Research Institute, Plovdiv, Bulgaria. HPLC grade acetone, methanol, tetrachloromethane, acetonitrile and methyl tert-butyl ether (MTBE) of analytical grade were purchased from Sigma, Germany. Carotenoid standards were supplied by Extrasynthese, France.

\section{Sample preparations}

The average laboratory sample $(10 \mathrm{~kg})$ of fresh red-ripe tomatoes was blanched at 95 ${ }^{\circ} \mathrm{C}$ for $2 \mathrm{~min}$, cooled in tap water and hand peeled. The obtained tomato peels quantity after 
peeling of each sample of different tomato cultivars was weighed and expressed as average percentage of peels. Than the samples were subsequently air-dried at $25 \pm 1{ }^{\circ} \mathrm{C}$, ground in a laboratory mill (Bosh MKM 6003, Germany) and sieved through a $1.0 \mathrm{~mm}$ sieve. The resultant material was kept in glass jars closed with aluminium foil at $-20{ }^{\circ} \mathrm{C}$ until the start of the experiments. The moisture content of the dry ground tomato peels was determined by gravimetric method at $105^{\circ} \mathrm{C}$.

\section{Carotenoids extraction}

To $0.1 \mathrm{~g}$ of dried and milled tomato peels sample was added $2 \mathrm{ml}$ of methanol and $5 \mathrm{ml}$ of tetrachloromethane and methanol mixture $(1: 3)$ and $0.5 \%$ of butylhydroxytoulene. The sample was placed for $15 \mathrm{~min}$ in an ultrasonic bath $(35 \mathrm{kHz})$ and after carotenoid extraction the $1 \mathrm{ml}$ of $10 \% \mathrm{NaCl}$ solution was added. The obtained extract was than centrifuged for 10 min at $5000 \mathrm{~min}^{-1}$ and the clear fraction was placed in a $5 \mathrm{ml}$ volumetric flask.

\section{HPLC analysis of carotenoids}

For the determination of carotenoids, the obtained extracts were analyzed using an HPLC system (Waters, Milford, USA) composed of a UV-VIS detector (Waters 2487 Dual ), a Waters 1525 binary pump and thermostat (LCO 102). The HPLC system was equipped with a $\mathrm{C}_{18}$ column, $25 \mathrm{~cm}$ x $4.6 \mathrm{~mm}, 51$ particle (Suspelco Discovery HS). Mobile phases of methanol:acetonitrile (A) in 8:2 ratio and MTBE (B) were used (Table 1). The flow rate was maintained at $1 \mathrm{ml} / \mathrm{min}$, the column temperature at $30{ }^{\circ} \mathrm{C}$, and detection was carried out at $270 \mathrm{~nm}$ and $290 \mathrm{~nm}$. The results are expressed in $\mathrm{mg} / 100 \mathrm{~g}$ dry matter.

\section{Environmental conditions measurement}

Data for average air temperature $\left({ }^{\circ} \mathrm{C}\right)$ and rainfall amount $\left(\mathrm{L} / \mathrm{m}^{2}\right)$ of the tomato openfield growing period in 2013 and 2014 crop years were obtained from the local research station of the Maritsa Vegetable Crop Research Institute, Plovdiv, Bulgaria.

\section{Statistical analysis}

All experiments were run in triplicate. The data were analyzed and presented as mean values with standard deviation. Statistical analysis was conducted using Statgraphics Centurion XVI Version 16.2.04 (Statpoint Technologies Inc., USA) и Microsoft Excel 2003 software. Statistical techniques, incl. Two-factor dispersion analysis, ANOVA and Duncan's Multiple Range Test, were applied. The significant differences were determined at $95 \%$ confidence $(\mathrm{P}<0.05)$ level.

Gradient profile of HPLC system for carotenoid analysis of tomato peels

Table 1

\begin{tabular}{|c|c|c|c|}
\hline Runs & Time, $\min$ & $\mathbf{A}, \%$ & $\mathbf{B}, \%$ \\
\hline 1 & 3.0 & 95 & 5 \\
\hline 2 & 3.0 & 95 & 5 \\
\hline 3 & 4.5 & 80 & 20 \\
\hline 4 & 5.0 & 65 & 35 \\
\hline 5 & 10.0 & 65 & 35 \\
\hline 6 & 10.1 & 95 & 5 \\
\hline 7 & 15.0 & 95 & 5 \\
\hline
\end{tabular}




\section{Results and discussion}

Six tomato cultivars for industrial processing were studied in the first year (2013) of survey. However, in the second crop year (2014), cultivars were reduced to four for the following reasons. The "Aquarius F1" and "Jaqueline" cultivars have almost the same chemical composition [6] and the average persentage of the peels was almost the same (Figure 1). In addition, "Aquarius F1" is a new and hybrid cultivar with a higher productivity and is preffered by the manufacturers in comparison to "Jaqueline" cultivar of tomato. Furthermore, the cultivars of "Marigold" and "Carobeta" are the same sort and the peels average persentage and beta-carotene content in the peels of "Marigold" is less than these in "Carobeta" (Figure 1 and Table 2). That's why the "Jaqueline" and "Marigold" tomato cultivars were dropped out of the 2014 survey.

The results obtained for avarege persentage of peels generated during the peeling of studied tomato cultivars are shown in Figure 1. The average persentage of peels from tomatoes harvested in 2013 year ranged from $2.45 \pm 0.13$ to $5.33 \pm 0.09 \%$. The highest persentage of peels was found for "Carobeta" cultivar and at least for "Topaz". For tomato cultivars cultivated in 2014 crop year the average persentage of the obtained peels varied from $2.98 \pm 0.13 \%$ to $3.50 \pm 0.25 \%$ and the highest quantity of peels was generated from the "Aquarius F1" cultivar and at least from "Carobeta" cultivar of tomato. No significant differences $(\mathrm{P}>0.05)$ were observed between the average persentage of peels for both "Aquarius F1" and "Stella" cultivars of tomato in 2013 crop year and for "Aquarius F1", "Stella" and "Topaz" for 2014 crop year.

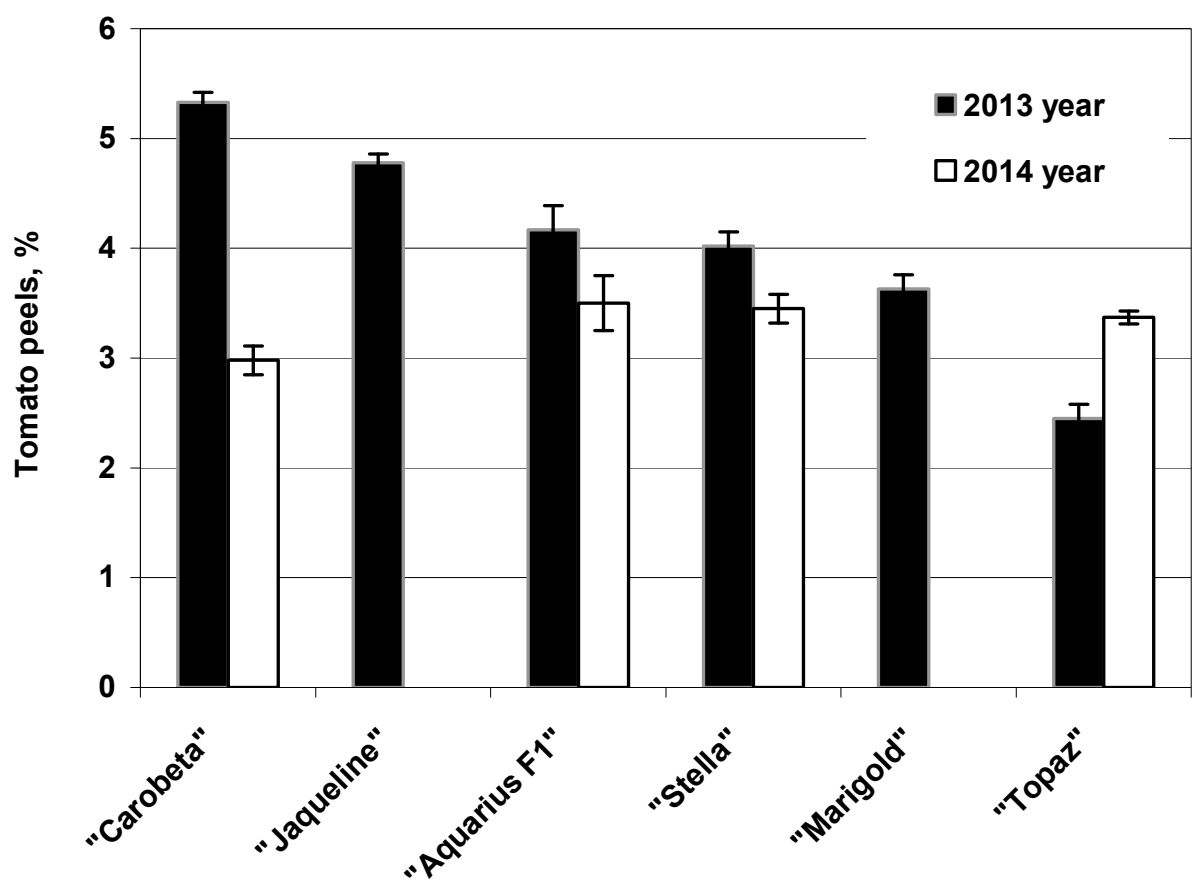

Figure 1. Average persentage of peels from different Bulgarian tomato cultivars (The data are means \pm standard deviation of three independent replicates) 

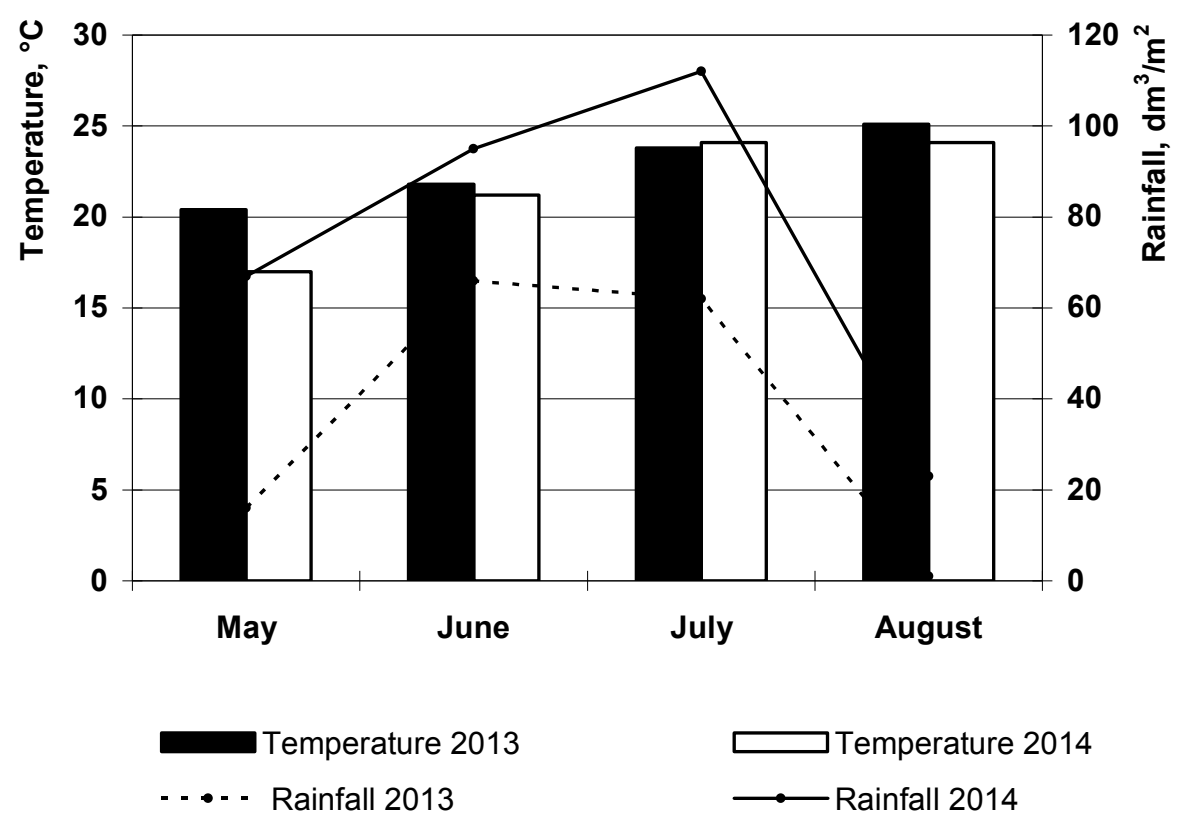

Figure 2. Average air temperature and rainfall amount of the tomato open-field growing period in 2013 and 2014 crop years

The results for average persentage of peels generated from different Bulgarian tomato cultivars (Figure 1) indicated that in addition to the tomato genotype, the environmental conditions of the investigated crop years probably had effect on peels quantity also. This fact is confirmed by the data of average air temperature and the amount of rainfall during tomato growing period in the two crop years which are presented in Figure 2. Data indicated that the air temperatures in 2013 and 2014 crop years were very closed, but the rainfall amount in the first year was much less than the second, which probably had affected the quantity of peels from the investigated tomato cultivars.

A quantitative and qualitative determinations of the carotenoids contained in tomato peels from different samples were performed by the HPLC analysis and the results obtained are summarized in Table 2. The data from carotenoids determination showed that the peels of studied tomato cultivars consisted mainly of lycopene, beta-carotene and lutein. In the first crop year the highest contents of lycopene $(97.16 \pm 0.81 \mathrm{mg} / 100 \mathrm{~g})$ and lutein $(21.22 \pm 0.10 \mathrm{mg} / 100 \mathrm{~g})$ were found in the peels of the "Stella" cultivar of tomato and those of "Carobeta" cultivar had the highest content of beta-carotene $(108.48 \pm 1.36 \mathrm{mg} / 100 \mathrm{~g})$, whereas in the second year of survey most of the lycopene $(241.14 \pm 1.24 \mathrm{mg} / 100 \mathrm{~g})$ was contained in the "Aquarius F1" peels, and the beta-carotene $(293.36 \pm 2.00 \mathrm{mg} / 100 \mathrm{~g})$ and lutein $(13.58 \pm 0.15 \mathrm{mg} / 100 \mathrm{~g})$ in the "Stella" tomato peels. 
Carotenoid content in the peels of different Bulgarian tomato cultivars

\begin{tabular}{|c|c|c|c|c|c|c|}
\hline \multirow[t]{2}{*}{$\begin{array}{l}\text { Tomato } \\
\text { cultivars }\end{array}$} & \multicolumn{2}{|c|}{$\begin{array}{l}\text { Lycopene, } \\
\mathrm{mg} / 100 \mathrm{~g}\end{array}$} & \multicolumn{2}{|c|}{$\begin{array}{c}\text { Beta-carotene, } \\
\mathrm{mg} / 100 \mathrm{~g}\end{array}$} & \multicolumn{2}{|c|}{$\begin{array}{l}\text { Lutein, } \\
\mathrm{mg} / 100 \mathrm{~g}\end{array}$} \\
\hline & 2013 year & 2014 year & 2013 year & 2014 year & 2013 year & 2014 year \\
\hline Stella & $\begin{array}{c}97.16 \pm \\
1.81^{\mathrm{aA}}\end{array}$ & $\begin{array}{c}167.86 \pm \\
2.15^{\mathrm{aB}}\end{array}$ & $\begin{array}{l}88.38 \pm \\
2.65^{\mathrm{aC}}\end{array}$ & $\begin{array}{c}293.36 \pm \\
2.00^{\mathrm{aD}}\end{array}$ & $\begin{array}{c}21.22 \pm \\
0.10^{\mathrm{aE}}\end{array}$ & $\begin{array}{c}13.58 \pm \\
0.15^{\mathrm{aF}}\end{array}$ \\
\hline Topaz & $\begin{array}{l}54.26 \pm \\
1.60^{\mathrm{bA}}\end{array}$ & $\begin{array}{c}167.40 \pm \\
1.42^{\mathrm{aB}}\end{array}$ & $\begin{array}{l}55.66 \pm \\
0.46^{\mathrm{bA}}\end{array}$ & $\begin{array}{l}46.03 \pm \\
0.44^{\mathrm{bC}}\end{array}$ & $\begin{array}{l}15.54 \pm \\
0.13^{\mathrm{bD}}\end{array}$ & $\begin{array}{l}11.48 \pm \\
0.10^{\mathrm{bE}}\end{array}$ \\
\hline $\begin{array}{l}\text { Aquarius } \\
\mathrm{F}_{1}\end{array}$ & $\begin{array}{c}26.97 \pm \\
1.09^{\mathrm{cA}}\end{array}$ & $\begin{array}{c}241.14 \pm \\
1.24^{\mathrm{bB}}\end{array}$ & $\begin{array}{l}38.17 \pm \\
0.91^{\mathrm{cC}}\end{array}$ & $\begin{array}{l}45.88 \pm \\
0.26^{\mathrm{bD}}\end{array}$ & $\begin{array}{l}11.65 \pm \\
0.09^{\mathrm{cE}}\end{array}$ & $\begin{array}{l}11.21 \pm \\
0.10^{\mathrm{cF}}\end{array}$ \\
\hline Jacqueline & $\begin{array}{l}20.34 \pm \\
0.25^{\mathrm{dA}}\end{array}$ & $*$ & $\begin{array}{l}32.52 \pm \\
0.49^{\mathrm{dB}}\end{array}$ & $*$ & $\begin{array}{l}11.56 \pm \\
0.16^{\mathrm{cC}}\end{array}$ & $*$ \\
\hline Marigold & $\begin{array}{l}15.89 \pm \\
0.15^{\mathrm{eA}}\end{array}$ & $*$ & $\begin{array}{l}83.52 \pm \\
0.10^{\mathrm{eB}}\end{array}$ & $*$ & $\begin{array}{l}11.30 \pm \\
0.28^{\mathrm{cC}}\end{array}$ & $*$ \\
\hline Carobeta & $\begin{array}{l}14.91 \pm \\
0.21^{\mathrm{fA}}\end{array}$ & $\begin{array}{l}14.51 \pm \\
0.57^{\mathrm{cA}}\end{array}$ & $\begin{array}{c}108.48 \pm \\
1.36^{\mathrm{fB}} \\
\end{array}$ & $\begin{array}{c}155.47 \pm \\
1.42^{\mathrm{cC}} \\
\end{array}$ & $\begin{array}{l}2.27 \pm \\
0.06^{\mathrm{dD}} \\
\end{array}$ & $\begin{array}{l}9.28 \pm \\
0.09^{\mathrm{dE}}\end{array}$ \\
\hline
\end{tabular}

* Not determined. The data are means \pm standard deviation of three independent replicates. The values with different small letters (a-f) and different capital letters (A-F) indicate significant differences between means values in the columns and rolls, respectively $(\mathrm{P}<0.05)$.

The results obtained for carotenoids content in the tomato peels (Table 2) were in agreement with data reprted from other reserches [9, 10, 14, 15] and showed differences in carotenoids content for different tomato cultivars which may be due to the genotype features. Differences in carotenoids content among tomato cultivars has been previously reported $[7,11]$. However, differences in carotenoids content between two crop years of the same cultivars were found also, probably due to different environmental conditions in 2013 and 2014 years, as indicated in Figure 2. Although tomatoes are irrigated crops, air temperature and humidity is important for the sinthesis of the substances in them. It has been reported that lycopene formation is favoured at temperatures ranging from 16 to $21^{\circ} \mathrm{C}$ and unfavoured at temperature values above $30^{\circ} \mathrm{C}$ [3]. Other studies have higlighted that the tomato nutrients, including lycopene, is affected by the soil water depletion even if it seems to be cultivar dependent $[3,4]$. Therefore, probably due to the less rainfall amount during tomato growing in 2013 crop year differences in both the persentage of the peels and their carotenoids content for the same tomato cultivars grown in 2013 and 2014 were observed.

The effects of genotype and crop year on the percentage of peels in tomatoes (Figure 3) and on the content of carotenoids in peels (Figures 4, 5 and 6) were established by performing of a two-factor dispersion analysis. The results indicated the greatest influence of the tomato genotype on lutein content $(69.43 \%)$, followed by beta-carotene $(57.52 \%)$ and peels persentage $(46.55 \%)$. The environmental conditions were found to had a strong influence on the content of peels $(41.66 \%)$ and lycopene $(38.73 \%)$, while the effect on betacarotene was lower $(14.92 \%)$ and on luteine was very low $(1.63 \%)$. 


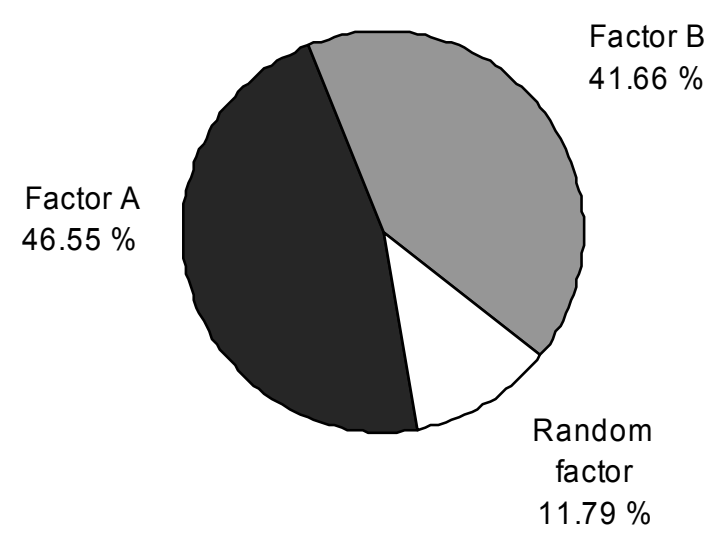

Figure 3. Influence of tomato genotype (Factor A) and crop year (Factor B) on the percentage of peels from six Bulgarian tomato cultivars

The results of the two-factor dispersion analysis (Figures 3, 4, 5, and 6) showed the major influence of the tomato genotype on the contents of tomato peels, beta-carotene and lutein, while the combined effect of genotype and crop year was found for persentage and lycopene content of the tomato peels. Data were in good acordance with other researches carried out for different tomato cultivars $[2,11]$.

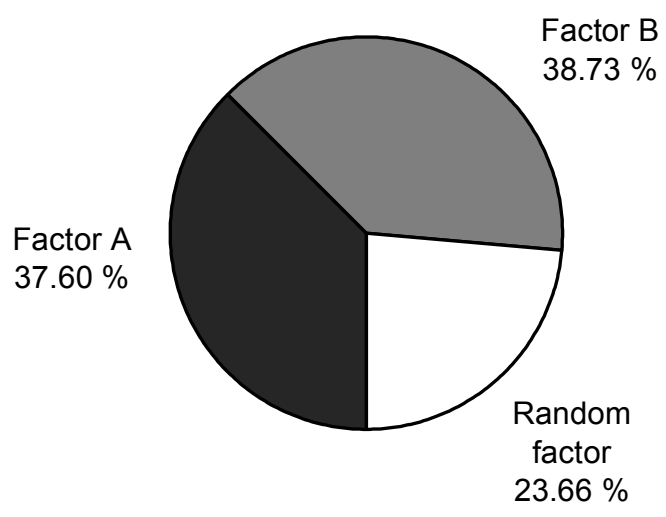

Figure 4. Influence of tomato genotype (Factor A) and crop year (Factor B) on the lycopene content of peels from six Bulgarian tomato cultivars 


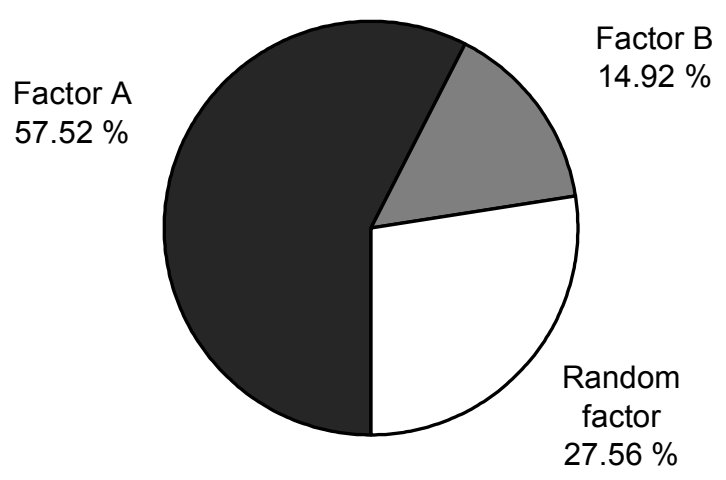

Figure 5. Influence of tomato genotype (Factor A) and crop year (Factor B) on the betacarotene content of peels from six Bulgarian tomato cultivars

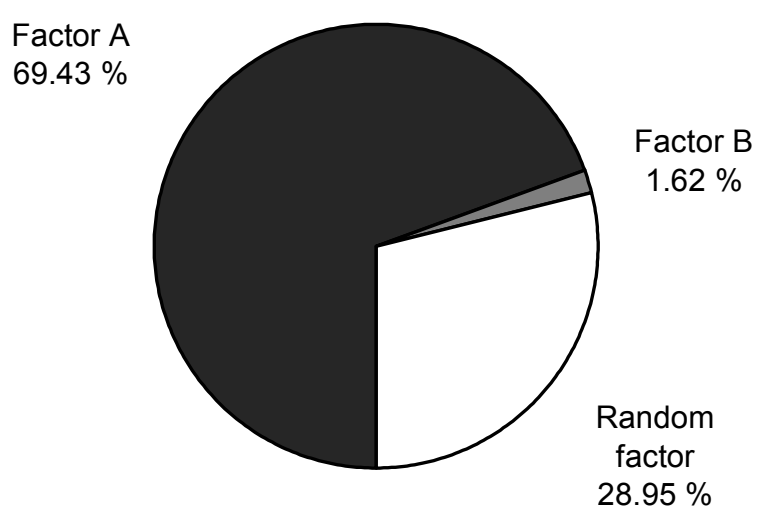

Figure 6. Influence of tomato genotype (Factor A) and crop year (Factor B) on the lutein content of peels from six Bulgarian tomato cultivars

\section{Conclusion}

The two-factor dispersion analysis was carried out to determined the combined effect of the tomato genotype and crop year on the amount of the waste peels generated during tomato peeling and by the HPLC analysis a characterization of the carotenoids contained in the tomato peels was made. The results indicated that obtained tomato peels contained mainly lycopene, beta-carotene and lutein. HPLC analysis showed that tomato peels of cultivars „Stella“, „Topaz“, „Aquarius $\mathrm{F}_{1}$ “ and „Jacqueline“ are reached in lycopene and beta-carotene, whereas the peels of cultivars „Marigold“ and „Carobeta“ are suitable source 
of beta-carotene only. Tomato genotype was found to had a major effect on the percentage of generated peels and on its carotenoids content. The amount of lycopene in tomato peels was dependent on both genotype and crop year, whereas the beta-carotene and lutein contents were affected mainly by the tomato genotype.

\section{Acknowledgements}

The authors would like to thank the Maritsa Vegetable Crop Research Institute, Plovdiv, Bulgaria and personally to Prof. Galina Pevicharova, $\mathrm{PhD}$ and Assoc. Prof. Daniela Ganeva, PhD for their support for tomato cultivars growing and distribution and for the experimental design help.

\section{References}

1. Al-Wandawi H., Abdul-Rahman M., Al-Shaikhly K. (1985), Tomato processing wastes as essential raw material sources, Journal of Agricultural and Food Chemistry, 33, pp. 804-807.

2. Brandt S., Lugasi A., Brana É., Hórváry J., Pék Z., Helyes L. (2003), Effects of the growing methods and conditions on the lycopene content of tomato fruits, Acta Alimentaria, 32(3), pp. 269-278.

3. Brandt S., Pék Z., Brana É., Lugasi A., Helyes A. (2006), Lycopene content and color of ripening tomatoes as affected by environmental conditions, Journal of the Science of Food and Agriculture, 86, pp. 568-572.

4. Dumas Y., Dadomo M., Di Lucca G., Grolier P. (2003), Effects of environmental factors and agricultural techniques on antioxidant content of tomatoes, Journal of the Science of Food and Agriculture, 83, pp. 369-382.

5. (2014), FAOSTAT, available at: www.faostat.fao.org.

6. Ganeva D., Pevicharova G. (2010), "Aquarius F1" new Bulgarian hybrid tomato cultivar for industrial processing, Bulgarian Journal of Crop Science, 47, pp. 379-384, (In Bulgarian).

7. George B., Kaur C., Khurdiya D., Kapoor H. (2004), Antioxidant in tomato (Lycopersicum esculentum) as a function of genotype, Food Chemistry, 84, pp. 45-51.

8. Hdider C., Ilahy R., Tlili I., Lenucci M., Dalessandro G. (2013), Effect of the stage of maturity on the antioxidant content and antioxidant activity of high-pigment tomato cultivars grown in Italy, Food, 7(Special Issue 1), pp. 1-7.

9. Ilahy R., Piro G., Tlili I., Riahi A., Sihem R., Onerghi I., Hdider C., Lenucci M. (2016), Fractionate analysis of the phytochemical composition and antioxidant activities in advanced breeding lines of high-lycopene tomatoes, Food and Function, 7, pp. 574-583.

10. Kalogeropoulos N., Chiou A., Pyriochou V., Peristeraki A., Karathanos V. (2012), Bioactive phytochemicals in industrial tomatoes and their processing by-products, LWT - Food Science and Technology, 49, pp. 213-216.

11. Kuti J., Konuru H. (2005), Effects of genotype and cultivation environment on lycopene content in red-ripe tomatoes, Journal of the Science of Food and Agriculture, 85, pp. 2021-2026. 


\section{- Food Technology —}

12. Lenucci M., Caccioppola A., Durante M., Serrone L., Honardo R., Piro G. (2010), Optimization of biological and physical parameters for lycopene supercritical $\mathrm{CO}_{2}$ extraction from ordinary and high-pigment tomato cultivars, Journal of the Science of Food and Agriculture, 90, pp. 1709-1718.

13. Nikolova M., Prokopov T., Ganeva D., Pevicharova G. (2014), Effect of treatment parameters on the carotenoid extraction from tomato peels of Bulgarian industrial varieties, Journal Food and Environment Safety of the Suceava University, 4, pp. 283 289.

14. Pevicharova G., Ganeva D. (2012), Antioxidants in parental components of F1 hybrids tomatoes for processing, Bulgarian Journal of Crop Science, 49, pp. 92-97, (In Bulgarian).

15. Savatović S., Ćetković G., Čanadanović-Brunet J., Djilas S. (2010), Utilization of tomato waste as a sourse of polyphenolic antioxidants, APTEFF, 41, pp. 1-203.

16. Strati I., Oreopoulou V. (2011), Effect of extraction parameters on the carotenoid recovery from tomato waste, International Journal of Food Science and Technology, $46(1)$, pp. 23-29. 